\title{
Analisis Tingkat Penerimaan Pengguna Terhadap SIMBUMIL (Hasil Survei Penerimaan SIMBUMIL di Puskesmas Mandalawangi)
}

\author{
Titin Pramiyati*, Jayanta, Halim Mahfud \\ Fakultas Ilmu Komputer \\ Universitas Pembangunan Nasional Veteran Jakarta \\ *titin.pramiyati@upnvj.ac.id
}

\begin{abstract}
Abstrak-Penerimaan Pengguna terhadap suatu sistem berbasis teknologi informasi dan komunikasi penting untuk dilakukan karena menjadi indikator bahwa sistem tersebut akan diterima dan digunakan oleh pengguna untuk mendukung penyelesaian atau pencapaian target pekerjaan. Pengukuran penerimaan Pengguna terhadap sistem informasi elektronik ibu hamil (SIMBUMIL) yang dilakukan pada penelitian ini, bertujuan untuk mengetahui penerimaan dan pendapat para Bidan sebagai Pengguna SIMBUMIL, berkaitan dengan aspek kemudahan, kegunaan, dan keinginan untuk menggunakan SIMBUMIL sebagai alat yang dapat mendukung pekerjaan. Penerimaan Pengguna terhadap SIMBUMIL dapat diketahui dengan mengukur penerimaan Pengguna terhadap SIMBUMIL. Metode yang digunakan untuk mengukur penerimaan Pengguna dilakukan dalam tiga tahap, yaitu tahap pelatihan, tahap survei, dan tahap analisis. Model pengukuran terhadap kemudahan, kegunaan, dan keinginan untuk menggunakan SIMBUMIL menggunakan Technology Acceptance Model (TAM). Aspek kemudahan diukur dengan menggunakan pertanyaan yang mewakili Variabel Perceived Ease of Use (PEU). Pengukuran kegunaan SIMBUMIL bagi Pengguna dilakukan dengan menggunakan Variabel Perceived of Usefullness (POU). Penerimaan Pengguna terhadap SIMBUMIL diketahui melalui pertanyaan untuk variabel use of SIMBUMIL. Hasil yang diperoleh dari pengukuran ini adalah Pengguna dapat menjelaskan kemudahan dan manfaat yang akan mereka dapatkan jika menggunakan SIMBUMIL, selain itu Pengguna juga dapat menentukan hal-hal yang harus dilakukan ketika menggunakan SIMBUMIL dalam pekerjaan seperti pemeriksaan yang lebih teliti karena hasil pemeriksaan akan digunakan oleh Pengguna lain.
\end{abstract}

Kata kunci: SIMBUMIL, Technology Acceptance Model, Variabel Perceived Ease of Use, Variabel Perceived of Usefullness

\section{Pendahuluan}

Sistem informasi adalah sistem yang menyediakan layanan untuk penyimpanan, pengambilan, koneksi, dan penilaian atas informasi. Informasi yang disimpan dan diambil kembali pada layanan kesehatan salah satunya adalah data klinik, [1]. Electronic Patient Record (EPR) adalah suatu sistem untuk pencatatan data medis pasien, yang memungkinkan informasi digunakan bersama sepanjang untuk kebutuhan kegiatan klinik dan berbagai fasilitas yang berhubungan dengan kegiatan klinik. EPR merupakan alat yang penting ketika dibutuhkan adanya perawatan yang dilakukan secara kolaboratif, yang melibatkan beberapa pelaksana perawatan [2]. Variabel manfaat memiliki pengaruh atas penerimaan sistem informasi pengolahan data statistik rutin [3]

Penerimaan Pengguna terhadap suatu sistem berbasis teknologi informasi dan komunikasi pada saat ini perlu dikaji, hal ini dikarenakan perkembangan Teknologi Informasi dan Komputer (TIK) yang semakin pesat dan sudah digunakan untuk mendukung pelayanan organisasi kepada Pengguna. Sistem dengan kemudahan dalam penggunaannya dan memiliki manfaat dapat mempengaruhi sikap Pengguna terhadap sistem informasi. Kemudahan dan manfaat menjadi variabel utama yang mempengaruhi penggunaan Sistem Manajemen Operasi Irigasi (SMOI) oleh penggunanya [4].

Persepsi atas kemanfaatan (perceived usefulness) didefinisikan oleh Fred Davis [5] sebagai "suatu tingkatan di mana seseorang percaya bahwa menggunakan sistem tersebut dapat meningkatkan kinerjanya dalam bekerja”. Attitude Toward Using dalam TAM dikonsepkan sebagai sikap terhadap penggunaan sistem yang berbentuk penerimaan atau penolakan sebagai dampak bila seseorang menggunakan suatu teknologi dalam pekerjaannya. Attitude Toward Using akan menentukan adanya minat (intention) untuk menggunakan atau tidak pada penggunaan sistem secara aktual. Minat pemanfaatan sistem tidak hanya dipengaruhi oleh persepsi tentang kegunaan teknologi (perceived usefulness), tetapi dipengaruhi juga oleh persepsi tentang kemudahan penggunaan teknologi (perceived ease of use).

Model TAM banyak digunakan pada beberapa penelitian yang dikhususkan pada penelitian yang 
berkaitan dengan penerimaan pengguna terhadap sistem berbasis TIK, seperti penelitian yang dilakukan untuk menganalisis penerimaan Pelanggan terhadap sistem informasi website Perusahaan Listrik Negara (PLN) [6], evaluasi penerimaan sistem informasi penasihat akademik [7], dan analisis penerimaan manajemen rumah sakit [8].

Pengukuran penerimaan pengguna sistem informasi Perpustakaan [9] terhadap Pustakawan dan Pemustaka, dan sistem pembelajaran elektronik [10]. Pengukuran penerimaan tidak saja dilakukan pada penerimaan terhadap sistem yang berbasis TIK, saat ini pengukuran sudah mengarah pada penerimaan teknologi [11].

Penerimaan para Bidan sebagai pelaksana dalam pemeriksaan kesehatan ibu hamil terhadap sistem informasi rekam medis SIMBUMIL menjadi topik pembahasan pada makalah ini. Penerimaan para Bidan sebagai Pengguna sistem menjadi penting karena dengan adanya kemauan para Bidan untuk menggunakan SIMBUMIL akan memudahkan proses pemeriksaan kesehatan ibu hamil dengan menggunakan data rekam medis secara bersama, sehingga dapat menurunkan angka kematian ibu (AKI).

Tahapan untuk mengukur penerimaan Pengguna terhadap SIMBUMIL dilakukan dalam tiga tahap, yaitu: tahap pelatihan, tahap survei, dan tahap analisis. Pengukuran penerimaan Pengguna terhadap SIMBUMIL menggunakan technology acceptance model (TAM). Hasil dari analisis yang dilakukan adalah para Bidan sebagai Pengguna SIMBUMIL akan menggunakan SIMBUMIL dalam mendukung pekerjaan mereka, karena kemudahan dan manfaat yag diberikan SIMBUMIL dapat memberikan pelayanan pemeriksaan kesehatan semakin baik dan menjangkau daerah yang luas, dan menimbulkan kesadaran bahwa proses pemeriksaan yang dilakukan harus lebih teliti karena data pemeriksaan yang akan dilakukan secara bersama.

\section{Metode}

\section{a. Metode Penelitian}

Analisis penerimaan terhadap SIMBUMIL dilakukan dengan tahapan pelatihan, survei, dan analisis, sebagaimana terlihat pada Gambar 1. Pelatihan penggunaan SIMBUMIL diberikan kepada para Bidan yang bertugas di Pusat Kesehatan Masyarakat (PKM) Mandalawangi sebanyak tiga Bidan, sedangkan pada praktik Bidan Halida diberikan pelatihan kepada satu Bidan. Kegiatan pelatihan terlebih dahulu dilakukan survei terhadap ketersediaan sambungan internet pada PKM dan praktik bidan. Ketersediaan sambungan internet sangat penting karena SIMBUMIL hanya dapat diakses melalui url:simbumil.com, Hasil survei ketersediaan sambungan internet, diperoleh data pada PKM Mandalawangi memiliki sambungan internet, sementara praktik Bidan Halida tidak tersedia sambungan internet.

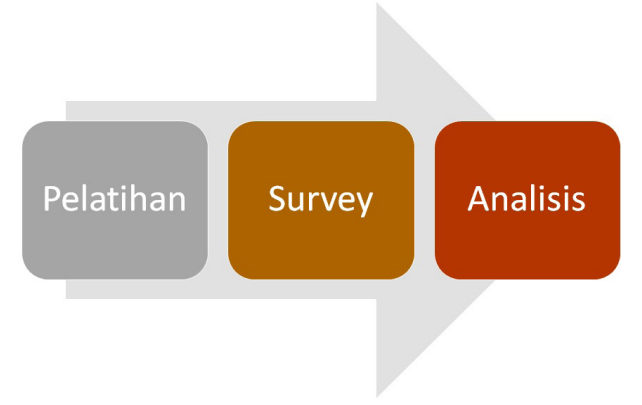

Gambar 1. Metode Penelitian

Ketersediaan sambungan internet di PKM Mandalawangi memudahkan pengujian SIMBUMIL, karena dengan sambungan internet yang tersedia dapat diketahui kecukupan lebar pita untuk mengakses SIMBUMIL. Sambungan internet yang tidak tersedia pada praktik Bidan Halida tidak menghambat proses pelatihan, karena SIMBUMIL dapat diakses dengan menggunakan smartphone, sehingga ketidaktersediaan sambungan internet dan perangkat komputer masih memungkinkan SIMBUMIL digunakan sebagai sarana prasarana pelayanan kesehatan ibu hamil.

Kegiatan survei dilakukan dengan cara wawancara kepada para Bidan yang sudah dilatih, dengan pertanyaan yang diberikan berkaitan dengan kemudahan, kegunaan atau manfaat, dan penerimaan pengguna terhadap SIMBUMIL. Pertanyaan yang diberikan kepada para Bidan menggunakan model Technology Acceptance Model (TAM), yaitu salah satu model yang dibangun untuk menganalisis dan memahami faktor-faktor yang mempengaruhi diterimanya penggunaan teknologi komputer. Arsitektur model TAM, terlihat pada Gambar 2.

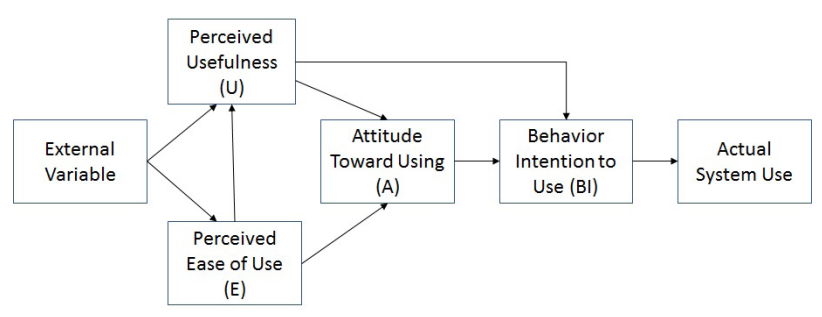

Gambar 2. Arsitektur TAM

\section{Hasil}

\section{a. Pelatihan Menggunakan SIMBUMIL}

Pelatihan penggunaan SIMBUMIL pertama kali menggunakan smartphone/handphone sebagai perangkat aksesnya. Sebelum memberikan pelatihan terlebih dahulu bidan ditanyakan tentang pengalaman menggunakan media sosial, pertanyaan ini penting untuk mengetahui kemampuan bidan dalam beradaptasi dengan proses registrasi pengguna dengan membuat username dan password. Pengalaman menggunakan media sosial akan memudahkan para bidan untuk menggunakan SIMBUMIL. Bidan yang tidak memiliki pengalaman 
menggunakan media sosial tentu harus dijelaskan terlebih dahulu fungsi dari username dan password yang harus dibuat untuk dapat mengakses SIMBUMIL.

Setelah membuat username dan password, para Bidan harus menunggu konfirmasi terhadap registrasi yang dibuat. Konfirmasi ini penting sebagai pengendali pengguna SIMBUMIL. Proses konfirmasi ini dapat digunakan sebagai bentuk pengamanan akses SIMBUMIL dari pengguna yang tidak bertanggung jawab. Saat ini proses konfirmasi masih dilakukan oleh penyedia sistem, ke depan jika SIMBUMIL sudah digunakan secara luas, proses konfirmasi dapat dilakukan oleh masing-masing penanggung jawab unit layanan kesehatan terkait. Setelah mendapat konfirmasi, para Bidan diminta untuk menjalankan SIMBUMIL dan memeriksa apakah data yang di-capture SIMBUMIL telah memenuhi kebutuhan rekam medis pemeriksaan ibu hamil. Pelaksanaan pelatihan dilakukan dengan membiarkan para bidan menjalankan aplikasi secara langsung, panduan akan diberikan ketika para Bidan membutuhkan penjelasan penggunaan aplikasi. Pelatihan ini dilakukan agar para Bidan dapat menilai kemudahan SIMBUMIL secara langsung.

Setelah selesai menggunakan SIMBUMIL dengan perangkat smartphone, berikutnya para Bidan diminta untuk menggunakan kembali SIMBUMIL dengan menggunakan perangkat lain, yaitu personal computer berupa desktop dan laptop. Pelatihan ini dilakukan untuk melihat apakah user experience SIMBUMIL sudah terpenuhi, dengan melihat pada kelancaran para Bidan melakukan login dan menjalankan proses lainnya, seperti input data hasil pemeriksaan yang dilakukan. Penggunaan perangkat yang berbeda pada saat pelatihan bertujuan untuk mendapatkan informasi perangkat yang memudahkan penggunaan SIMBUMIL oleh para Bidan.

Kelengkapan data pada SIMBUMIL juga diperlihatkan pada saat pelatihan kepada para Bidan, hal ini bertujuan untuk mendapatkan umpan balik agar data yang di-capture oleh SIMBUMIL lebih lengkap. Data yang menjadi perhatian dari para Bidan adalah data yang berisi informasi tanggal menstruasi terakhir sebelum hamil, yang berguna untuk menghitung usia kehamilan. Kelengkapan data ini juga dikonfirmasi kembali, berkaitan dengan kebutuhan data yang dapat digunakan untuk menentukan penyulit kehamilan yang mungkin timbul.

\section{b. Survei}

Penelitian yang dilakukan Muntianah [12], menyebutkan bahwa persepsi kemudahan penggunaan Teknologi Informasi (TI) berpengaruh pada persepsi kemanfaatan, dalam arti apabila pengguna TI merasa mudah menggunakan TI nya maka dia juga akan berpendapat bahwa TI itu bermanfaat. Hasil penelitian Nurmaini [6] menunjukkan bahwa kemudahan sistem berbasis TI berpengaruh positif terhadap variabel penerimaan. Berdasarkan pada kedua penelitian ini, wawancara yang dilakukan kepada Bidan bertujuan untuk mendapatkan informasi kemudahan, manfaat, dan penerimaan Bidan terhadap SIMBUMIL.
Data yang digunakan dalam penelitian ini diperoleh dengan melakukan wawancara dengan pengguna (para Bidan) dengan memberikan pertanyaan yang merupakan variabel yang diteliti yang dinotasikan dengan P-1, P-2, P-3, P-4, dan P-5. Variabel Perceived Ease of Use (PEU) atau persepsi tentang kemudahan SIMBUMIL dilakukan dengan menggunakan pertanyaan:

1. Apakah SIMBUMIL mudah digunakan?

2. Apakah Registrasi Pengguna mudah digunakan?

3. Proses apakah yang dirasa sulit dari SIMBUMIL?

4. Apakah Pengisian data pemeriksaan mudah digunakan?

5. Perangkat apa yang menjadikan SIMBUMIL lebih mudah digunakan? (Smartphone/HP, PC desktop, Laptop) Hasil wawancara diperoleh jawaban sebagaimana terlihat pada Tabel 1, yang memperlihatkan bahwa persepsi kemudahan SIMBUMIL secara umum adalah 'Mudah'. Kesimpulan ini diambil berdasarkan pada jawaban yang diberikan oleh para Bidan terhadap pertanyaan P-1, P-2, dan P-3. Jawaban pertanyaan P-4 dengan jawaban yang diberikan berkaitan dengan proses pencarian pasien yang dianggap sulit dikarenakan proses pencarian pasien dilakukan dengan memasukkan nama pasien seperti terlihat pada Gambar 3, bukan dengan memasukkan kode, seperti nomor identitas pasien, yang umum digunakan.

Tabel 1. Hasil wawancara untuk persepsi kemudahan SIMBUMIL

\begin{tabular}{|c|c|c|c|c|c|}
\hline Bidan & P-1 & P-2 & P-3 & P-4 & P-5 \\
\hline Bidan1 & Mudah & Mudah & $\begin{array}{l}\text { Pe n c a r i a } \mathrm{n} \\
\text { Pasien yang } \\
\text { berkunjung }\end{array}$ & Mudah & $\mathrm{HP}$ \\
\hline Bidan2 & Mudah & Mudah & $\begin{array}{l}\text { Ke sala ha } \\
\text { d a l a m } \\
\text { penggunaan } \\
\text { Nama sebagai } \\
\text { username }\end{array}$ & Mudah & HP \\
\hline Bidan3 & Mudah & Mudah & $\begin{array}{l}\text { Pencarian } \\
\text { Pasien }\end{array}$ & Mudah & $\begin{array}{l}\text { HP (layar } \\
\text { k e cil), } \\
\text { la p to p } \\
\text { l a y e r } \\
\text { l e b i h } \\
\text { lebar }\end{array}$ \\
\hline Bidan4 & Mudah & Mudah & $\begin{array}{l}\text { P e n c a r i a n } \\
\text { Pasien karena } \\
\text { j e n d e l a } \\
\text { pencarian yang } \\
\text { kosong }\end{array}$ & Mudah & HP \\
\hline
\end{tabular}

Pencarian pasien yang dirasakan oleh para Bidan menjadi proses yang sulit, dikarenakan pada jendela dari proses ini hanya tersedia jendela Search tanpa diberikan pesan bagaimana menggunakan jendela Search sebagai tempat untuk menempatkan nama Pasien yang akan diperiksa. Ketersediaan antar muka seperti ini akan membingungkan bagi pengguna karena tidak ada informasi lain atau arahan penggunaan proses ini. Penggunaan kata Pencarian menggantikan kata Search akan memudahkan pengguna untuk memahami apa yang harus dilakukan dengan jendela tersebut. 


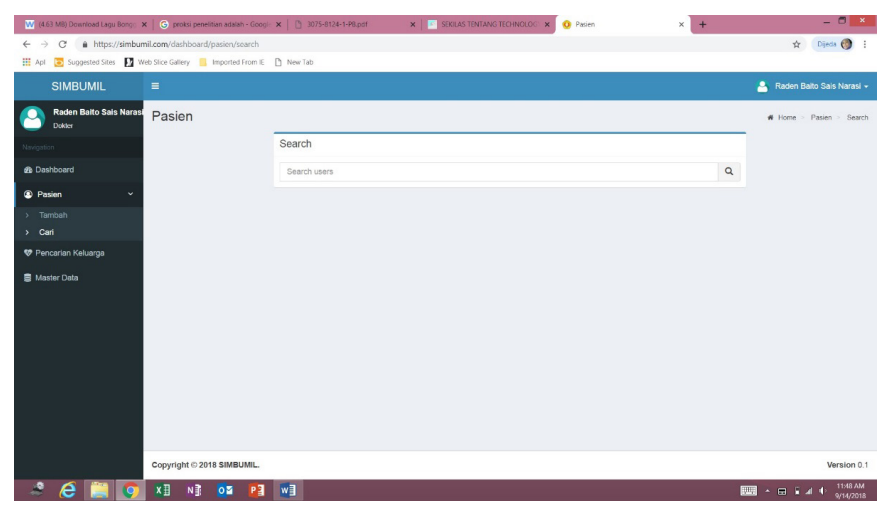

Gambar 3. Jendela proses pencarian Pasien

Tabel 2. Pengukuran kegunaan SIMBUMIL

\begin{tabular}{|c|c|c|c|}
\hline Bidan & P-1 & P-2 & P-3 \\
\hline Bidan 1 & $\begin{array}{l}\text { Data yang direkam } \\
\text { dapat digunakan } \\
\text { oleh Bidan lainnya }\end{array}$ & Ya, sangat bermanfaat & $\begin{array}{l}\text { Menjadikan Bidan harus lebih } \\
\text { hati-hati dalam pemeriksaan }\end{array}$ \\
\hline Bidan 2 & $\begin{array}{l}\text { Mudah mencatat } \\
\text { hasil pemeriksaan }\end{array}$ & Bermanfaat & $\begin{array}{l}\text { Mengetahui Bidan/Dokter } \\
\text { yang memeriksa sebelumnya }\end{array}$ \\
\hline Bidan 3 & Rekam Medis & Bermanfaat & Datanya lengkap \\
\hline Bidan 4 & $\begin{array}{l}\text { SIMBUMIL dapat } \\
\text { diakses pakai HP }\end{array}$ & $\begin{array}{l}\text { Bermanfaat karena masih ada pasien } \\
\text { yang ke Dukun (paraji), karena } \\
\text { letak PKM yang jauh. SIMBUMIL } \\
\text { memungkinkan pemeriksaan } \\
\text { dengan pola jemput bola }\end{array}$ & Data pemeriksaan lengkap \\
\hline
\end{tabular}

Pertanyaan P-5 yang diberikan kepada pengguna berkaitan dengan perangkat yang menjadi pilihan dalam menggunakan SIMBUMIL bertujuan untuk mengetahui perangkat yang sesuai digunakan oleh para Bidan dalam menjalankan aplikasi SIMBUMIL. Hasil wawancara diperoleh kesimpulan bahwa smarphone (handphone/HP) adalah pilihan para Bidan untuk menjalankan SIMBUMIL. Pemilihan smartphone/ handphone dikarenakan SIMBUMIL dirancang dengan memperhatikan aspek responsive yang memungkinkan SIMBUMIL nyaman digunakan dengan perangkat smartphone/handphone.

Jawaban yang diberikan oleh Bidan3 yang menyatakan bahwa menggunakan smartphone mudah hanya saja layar terlalu kecil sehingga pembacaan data pada form yang harus diisi tidak secara lengkap terbaca. Berdasarkan jawaban yang diberikan oleh Bidan3, maka ketersediaan perangkat desktop atau laptop dengan layar sentuh dapat menjadi solusi keterbatasan ukuran layar smartphone. Hasil wawancara ini dapat dijadikan sebagai dasar pada arsitektur penerapan SIMBUMIL yang berkaitan dengan perangkat Pengguna.

Pengukuran kegunaan SIMBUMIL pada Tabel 2 bagi Pengguna dalam hal ini adalah para Bidan dilakukan dengan menggunakan Variabel Perceived of Usefullness (POU) atau persepsi tentang kemanfaatan SIMBUMIL dalam pekerjaan yang diukur dengan 3 pertanyaan, yaitu:
1. Apa yang dapat dimanfaatkan dari SIMBUMIL?

2. Apakah SIMBUMIL akan bermanfaat?

3. Manfaat lain dari SIMBUMIL?

Jawaban yang diberikan oleh pengguna sebagaimana terlihat pada Tabel 2., digunakan untuk mengetahui kegunaan dan manfaat dari SIMBUMIL menurut pengguna. Sesuai dengan pertanyaan yang diajukan, diperoleh jawaban yang secara keseluruhan menunjukkan SIMBUMIL memiliki manfaat dalam mendukung pelayanan pemeriksaan kehamilan. Pengguna SIMBUMIL dalam menjawab Pertanyaan P-1 memberi jawaban sesuai dengan manfaat yang dirasakan oleh masing-masing Pengguna, sehingga diperoleh beragam jawaban yang mencerminkan bahwa keberadaan SIMBUMIL akan memberi manfaat dari berbagai aspek. Salah satu manfaat yang dirasa oleh Bidan adalah manfaat SIMBUMIL yang dilihat dari aspek perangkat yang dapat digunakan untuk mengakses SIMBUMIL.

Pertanyaan P-2 diberikan untuk mengetahui persepsi Pengguna terhadap SIMBUMIL, jawaban yang diperoleh menyatakan SIMBUMIL bermanfaat. Kebermanfaatan SIMBUMIL secara rinci diberikan oleh Bidan3 yang menyatakan bahwa SIMBUMIL dapat digunakan untuk menunjang pemeriksaan ibu hamil yang berada jauh dari lokasi PKM. SIMBUMIL yang dapat diakses menggunakan smartphone/handphone menjadikan 
adanya pandangan bahwa SIMBUMIL dapat mendukung pemeriksaan yang dilakukan dengan pendekatan "jemput bola”, karena pencatatan pemeriksaan dapat dilakukan pada saat itu juga, dan kebutuhan riwayat pemeriksaan dapat dengan cepat diketahui.

Pertanyaan P-3 yang ditanyakan kepada Pengguna bertujuan untuk mengetahui manfaat lain dari SIMBUMIL menurut pengguna. Berdasarkan pada kelengkapan data yang disediakan pada SIMBUMIL, dua orang Pengguna memberi jawaban bahwa SIMBUMIL menyediakan data yang lengkap terkait dengan data rekam medis, dan data berkaitan dengan ketersedian data histori pemeriksaan dan persalinan. Jawaban lain yang diberikan untuk pertanyaan P-3 adalah sikap hati-hati yang harus diperhatikan pada saat pemeriksaan kehamilan, karena data rekam medis yang dicatatkan digunakan secara bersama dengan pengguna lain. Melalui pertanyaan P-3 ini manfaat SIMBUMIL yang teridentifikasi tidak hanya berkaitan dengan sistem dan data akan tetapi juga berkaitan dengan perilaku pelaksana pemeriksa kesehatan berkaitan dengan akurasi data yang disediakan oleh SIMBUMIL.
Penerimaan adalah keinginan pengguna untuk menggunakan teknologi yang telah dirancang untuk mendukung tugasnya. Penerimaan SIMBUMIL oleh Pengguna diukur menggunakan variabel Penerimaan (Use of SIMBUMIL), tiga pertanyaan yang digunakan sebagai berikut:

1. Apakah SIMBUMIL akan digunakan?

2. Alasan untuk menggunakan SIMBUMIL?

3. Apakah SIMBUMIL mendukung pekerjaan/profesi?

Jawaban atas pertanyaan P-1, P-2, dan P-3 menunjukkan bahwa penerimaan pengguna terhadap SIMBUMIL dalam menunjang pekerjaan/profesi Bidan sangat positif seperti terlihat pada Tabel 3. Penerimaan ini sangat relevan dengan tuntutan dari Pemerintah bahwa pelayanan kesehatan untuk masyarakat harus berbasis TIK. Selain itu pemahaman terhadap manfaat dan fungsi SIMBUMIL yang menyediakan penggunaan secara bersama serta memberikan informasi yang lengkap terkait dengan rekam medis dan pelaksana pemeriksa kesehatan menjadikan SIMBUMIL dapat diterima.

Tabel 3. Pertanyaan untuk mengukur Penerimaan Pengguna

\begin{tabular}{|c|c|c|c|}
\hline Bidan & P-1 & P-2 & P-3 \\
\hline Bidan1 & $\begin{array}{l}\text { Ya digunakan, karena banyak } \\
\text { manfaatnya }\end{array}$ & $\begin{array}{l}\text { PKM harus sudah berbasis TIK } \\
\text { dalam Pelayanan Kesehatan } \\
\text { kepada masyarakat }\end{array}$ & $\begin{array}{l}\text { Ya, adanya rekam medis setiap } \\
\text { pemeriksaan dapat diketahui }\end{array}$ \\
\hline Bidan2 & $\begin{array}{l}\text { Ya digunakan karena mudah } \\
\text { dan data yang direkam lengkap }\end{array}$ & $\begin{array}{l}\text { SIMBUMIL dapat menjadi } \\
\text { program unggulan PKM dalam } \\
\text { pelayanan kepada masyarakat }\end{array}$ & $\begin{array}{l}\text { Ya, adanya SIMBUMIL dapat } \\
\text { menarik masyarakat untuk } \\
\text { memeriksa kehamilan di PKM }\end{array}$ \\
\hline Bidan3 & Digunakan & $\begin{array}{l}\text { Data pemeriksaan dapat } \\
\text { diketahui dengan lengkap }\end{array}$ & $\begin{array}{l}\text { Ya, dapat mengetahui apakah } \\
\text { ibu hamil menjaga atau } \\
\text { meningkatkan kesehatan } \\
\text { kehamilannya atau tidak }\end{array}$ \\
\hline Bidan4 & $\begin{array}{l}\text { Ya, berguna untuk merekam } \\
\text { data pemeriksaan }\end{array}$ & $\begin{array}{l}\text { Bidan dapat menggunakan } \\
\text { hasil pemeriksaan yang } \\
\text { dilakukan oleh Bidan lain, } \\
\text { sehingga dapat berkomunikasi } \\
\text { untuk memastikan kebenaran } \\
\text { data }\end{array}$ & $\begin{array}{l}\text { Sangat menunjang, terlebih } \\
\text { untuk menjangkau masyarakat } \\
\text { yang masih menggunakan jasa } \\
\text { dukun (paraji) }\end{array}$ \\
\hline
\end{tabular}

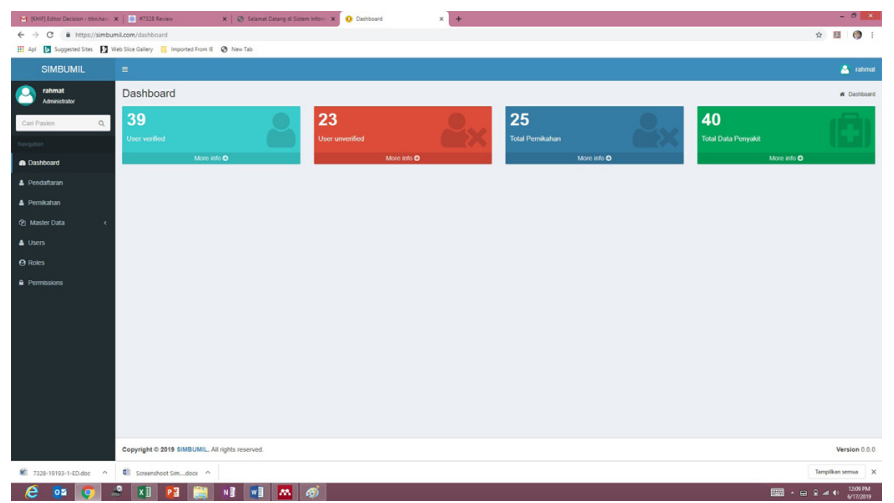

Gambar 4. Dashboard SIMBUMIL

Survei yang sama juga dilakukan terhadap 39 Bidan setelah diperoleh hasil survei sebelumnya. Survei ini dilakukan untuk memastikan bahwa penggunaan SIMBUMIL dapat dilakukan oleh Bidan lain. Hasil dari survei terhadap 39 Bidan memberikan kesan bahwa SIMBUMIL dapat diterima dan mudah digunakan, Permasalahan yang menjadi perhatian 39 Bidan adalah penggunaan nama atribut yang menggunakan istilah medis, seperti atribut engagement, 
dan beberapa istilah lain yang berbeda dengan istilah yang digunakan. Survei terhadap 39 Bidan yang menggunakan SIMBUMIL dapat dilihat pada dashboard SIMBUMIL yang memperlihatkan jumlah bidan yang mengakses SIMBUMIL seperti terlihat pada Gambar 4.

\section{c. Anlisis}

Berdasarkan pada hasil wawancara dengan beberapa pertanyaan yang diajukan kepada para Bidan, hamper semua Bidan menyatakan bahwa SIMBUMIL mudah digunakan, terlebih jika menggunakan perangkat smartphone, hal ini dikarenakan pengisian data rekam medis yang disajikan oleh SIMBUMIL berupa pilihan yang sesuai dengan hasil pemeriksaan yang dilakukan, misal hasil pemeriksaan detak jantung, hanya diisi dengan normal dan tidak normal. Penggunaan SIMBUMIL dengan menggunakan perangkat smartphone, dapat memberi kemudahan para Bidan untuk melakukan pengisian rekam medis ketika mereka sedang melakukan pemeriksaan pada lokasi yang berjauhan dengan PKM, dan pemberian layanan ke lokasi yang jauh dari lokasi PKM akan menurunkan jumlah ibu hamil yang memeriksakan kesehatan kehamilan ke paraji (dukun).

Kemudahan dalam penggunaan SIMBUMIL dapat memicu para Bidan untuk mengidentifikasi manfaat dari SIMBUMIL dengan baik, hal ini dapat terlihat dari jawaban atas pertanyaan yang diberikan berkaitan dengan aspek manfaat. Tanggapan terbaik yang diberikan adalah manfaat SIMBUMIL yang menyadarkan para Bidan untuk melakukan pemeriksaan kesehatan harus lebih teliti, karena penggunaan rekam medis yang digunakan secara bersama oleh Bidan lainnya. Kelengkapan data yang disediakan oleh SIMBUMIL menjadi salah satu faktor penerimaan para Bidan terhadap SIMBUMIL, informasi ini diberikan pada tahap pelatihan, dan wawancara untuk mengetahui apakah atribut pada basisdata SIMBUMIL sudah lengkap dan sesuai dengan pelaksanaan pemeriksaan kesehatan yang harus dilakukan.

Satu hal penting yang menjadi perhatian dalam pengukuran penerimaan SIMBUMIL ini adalah jawaban yang diberikan oleh Bidan terkait dengan penggunakan perangkat laptop, di mana penggunaan laptop memberikan keleluasaan dalam melihat tampilan aplikasi. Jawaban ini tidak menjadikan SIMBUMIL tidak dapat diterima, akan tetapi menjadi masukan dalam penyediaan perangkat keras berupa komputer dengan layar sentuh sebagai alat inputnya.

\section{Kesimpulan}

Uji coba SIMBUMIL yang dilaksanakan pada PKM Kecamatan Mandalawangi memberi gambaran bagaimana para Bidan sebagai pengguna SIMBUMIL memberikan respon terhadap SIMBUMIL dalam bentuk pemahaman SIMBUMIL dalam mendukung pekerjaan/profesi para Bidan. Penjelasan cara kerja dan fungsi SIMBUMIL yang diberikan melalui pelatihan, memberi pemahaman para Bidan bahwa penggunaan SIMBUMIL akan membutuhkan pemeriksaan kehamilan yang lebih teliti, karena data rekam medis SIMBUMIL dapat digunakan secara bersama diantara para Bidan.

Hasil uji coba dan survei terhadap penerimaan dan kegunaan SIMBUMIL menurut sudut pandang pengguna membantu dalam menentukan perangkat keras yang digunakan. Penggunaan PC dengan teknologi NUC dan layer sentuh menjadi pilihan sesuai dengan persepsi yang diberikan oleh pengguna bahwa menggunakan smartphone/handphone lebih mudah mengoperasikan SIMBUMIL.

\section{Persantunan}

Terimakasih diucapkan kepada DPRM Kemeristekdikti yang telah membiayai penelitian sehingga dihasilkan makalah ilmiah ini.

\section{Daftar Pustaka}

[1] B. A. Levine, G. S. Norton, and S. K. Mun, "Information Systems and Integration 2 . Medical Information Systems 3 . Image Management and Communication Systems," Evolution (N. Y)., pp. 9-13, 1996.

[2] A. Horsch and T. Balbach, "Telemedical information systems.," IEEE Trans. Inf. Technol. Biomed., vol. 3, no. 3, pp. 166-75, Sep. 1999.

[3] S. Monalisa and P. Setia Dwi, "Analisis Penerimaan Sistem Iinformasi Pengolahan Data Statistik Rutin ( SISR ) Menggunakan Metode Technology Acceptance Model ( Studi Kasus: BKKBN Provinsi Riau )," Rekayasa dan Manaj. Sist. Inf., vol. 2, no. 1, pp. 50-53, 2016.

[4] M. D. Joubert and A. Prihantoko, "Analisa Keberterimaan Pengguna Terhadap Aplikasi Sistem Manajemen Operasi Irigasi Menggunakan Technology Acceptance Model (Studi Kasus Daerah Irigasi Boro, Purworejo),” J. Irig., vol. 10, no. 1, pp. 11-20, 2015.

[5] F. D. Davis, "Perceived Usefulness, Perceived Ease of Use, and User Acceptance of Information Technology,” MIS Q., vol. 13, no. 3, p. 319, 1989.

[6] D. Nurmaini and M. Ger, "Analisis penerimaan pelanggan terhadap sistem informasi website pln dengan model tam," in Seminar Nasional Sistem Informasi Indonesia, 2016, no. November.

[7] U. Dyah Retno and A. Wibowo, "Evaluasi Penerimaan Sistem Informasi Dengan Pendekatan Teori Technology Acceptance Model ( TAM ) ( Studi Kasus : Sistem Informasi Penasehat Akademik Universitas Budi Luhur )," in Digital Information \& System Confeerence, 2009, no. October 2009, pp. 14-23.

[8] E. Saputra and Misfariyan, "Analisa Penerimaan 
Sistem Informasi Manajemen Rumah Sakit Umum Daerah Bangkinang Menggunakan Metode Technology Acceptance Model ( TAM ).”

[9] F. Endang, "Technology Acceptance Model (TAM) Untuk Menganalisis Penerimaan Terhadap Sistem Informasi Perpustakaan,” Iqra, vol. 09, no. 01, pp. 1-13, 2015.

[10] F. Amalia and A. H. Brata, "Analisis Tingkat Penerimaan Sistem E-Learning menggunakan Blog Gratis sebagai Alternatif Media Pembelajaran pada Guru," J. Teknol. Inf. dan Ilmu Komput., vol. 5, no. 3, p. 335, 2018.

[11] F. Pradana, A. Rachmadi, and F. A. Bachtiar, "Penilaian Faktor Penerimaan Teknologi Blended learning di PTIIK Universitas Brawijaya dengan Metode Unified Theory of Acceptance and Use of Technology (UTAUT)," J. Teknol. Inf. dan Ilmu Komput., vol. 2, no. 1, p. 49, 2017.

[12] S. T. Muntianah, E. S. Astuti, and D. F. Azizah, "Pengaruh Minat Perilaku Terhadap Actual Use Teknologi Informasi dengan Pendekatan Technology Acceptance Model (TAM) (Studi Kasus Pada Kegiatan Belajar Mahasiswa Fakultas Ilmu Administrasi Universitas Brawijaya Malang)," Profit (Jurnal Adm. Bisnis), vol. 6, no. 1, pp. 88-113, 2012. 